\title{
A COMPREHENSIVE PRACTICAL GEOMETRY FOR BUILDERS
}

A.B.Emary

F.B.I.C.C.

$\mathbf{M}$ 
(C) A. B. Emary 1981

All rights reserved. No part of this publication may be reproduced or transmitted, in any form or by any means, without permission.

First published 1981 by THE MACMILLAN PRESS LTD

London and Basingstoke Companies and representatives throughout the world

ISBN 978-0-333-31974-1

ISBN 978-1-349-06092-4 (eBook) DOI 10.1007/978-1-349-06092-4

By the same author Carpentry, Joinery and Machine Woodworking (Wood Trades Part 1) Carpentry and Joinery (Wood Trades Part 2)

The paperback edition of this book is sold subject to the condition that it shall not, by way of trade or otherwise, be lent, resold, hired out or otherwise circulated without the publisher's prior consent

in any form of binding or cover other than that in which it is published and without a similar condition including this condition being imposed on the subsequent purchaser. 


\section{Contents}

Introduction

1. Producing a geometrical drawing

2. Definitions and simple exercises

3. Quadrilaterals and triangles

4. Scale of chords

5. Regular and irregular polygons

6. Areas of plane figures

7. The circle

8. Arches

9. Tracery design and loci

10. The ellipse

11. The parabola

12. Irregular curves $v$ 13. Entasis of a column

36

1 14. Roman and Grecian mouldings

37

2 15. Enlarging and reducing drawings

40

$5 \quad$ 16. Raking mouldings

43

$9 \quad$ 17. Inclined and oblique surfaces

46

10 18. Pipe bending

51

13 19. Pictorial drawings

52

16 20. Orthographic projections

56

22

21. Prisms and related examples

59

25

22. Pyramids and related examples

73

30

23. The cylinder and related examples

79

33

24. The cone and related examples

86

35 25. The sphere and related examples

36

40

3

6

1


26. Domes, dormer and turret roofs

27. Scrolls, volutes and spirals

28. The helix and spiral staircases

29. Geometrical staircases
96 30. Handrailing - one-bevel work

108

100 31. Handrailing - two-bevel work

103 32. Machine cutters

105 33. Double-curvature work 


\section{Introduction}

Geometry, to many people, has always been an absorbing subject. Craftsmen have to resort to geometry to enable them to do work, which, without it, would be either impossible to complete, or at best, would compel them to adopt trial and error methods leading, in many cases, to inaccuracies and bad workmanship and uneconomical ways of producing work.

A Comprehensive Practical Geometry for Builders has been produced to assist the craftsmen in the various sections of the building trade to surmount many of the obstacles they come face to face with in their work so that these problems can be efficiently dealt with, leading one, it is hoped, to a satisfactory conclusion of the work in hand. Also, those who are attending courses in building and related subjects at technical colleges should find the book of great value.
The work within these pages deals with the majority of the problems met with today in building, and each problem has been explained in the simplest of ways. All the preliminaries leading up to the problems have been dispensed with, leaving the bare, hard facts on how each problem can be solved.

Some of the problems chosen will sometimes seem to have no bearing at all with present-day methods - the reader is asked to bear with the author who is certain that the theory behind the problem will be useful in one way or another.

A list of basic drawing instruments and accessories for making drawing easier have been included in the book, although most people know what they require for their own particular work and the younger person usually has instruction in these things at the local technical college. 